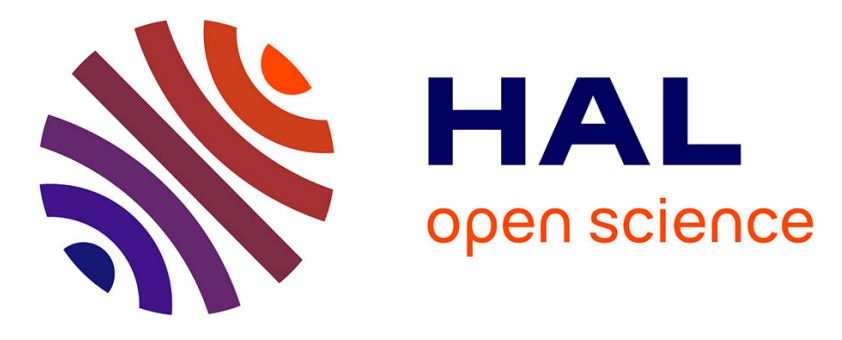

\title{
Phytolith assemblages as a promising tool for reconstructing Mediterranean Holocene vegetation
}

Claire Delhon, Anne Alexandre, Jean-François Berger, Stephanie Thiebault, Jacques-Léopold Brochier, Jean-Dominique Meunier

\section{- To cite this version:}

Claire Delhon, Anne Alexandre, Jean-François Berger, Stephanie Thiebault, Jacques-Léopold Brochier, et al.. Phytolith assemblages as a promising tool for reconstructing Mediterranean Holocene vegetation. Quaternary Research, 2003, 59 (1), pp.48-60. hal-01909885

\section{HAL Id: hal-01909885 \\ https://hal.science/hal-01909885}

Submitted on 17 Dec 2018

HAL is a multi-disciplinary open access archive for the deposit and dissemination of scientific research documents, whether they are published or not. The documents may come from teaching and research institutions in France or abroad, or from public or private research centers.
L'archive ouverte pluridisciplinaire HAL, est destinée au dépôt et à la diffusion de documents scientifiques de niveau recherche, publiés ou non, émanant des établissements d'enseignement et de recherche français ou étrangers, des laboratoires publics ou privés. 


\title{
Phytolith assemblages as a promising tool for reconstructing Mediterranean Holocene vegetation
}

\author{
Claire Delhon, ${ }^{\mathrm{a}, *}$ Anne Alexandre, ${ }^{\mathrm{b}}$ Jean-François Berger, ${ }^{\mathrm{c}}$ Stéphanie Thiébault, ${ }^{\mathrm{a}}$ \\ Jacques-Léopold Brochier, ${ }^{\mathrm{d}}$ and Jean-Dominique Meunier ${ }^{\mathrm{b}}$ \\ a ArScAn, Maison de l'Archéologie et de l'Ethnologie, 21 Allée de l'Université, F92023 Nanterre Cedex, France \\ ${ }^{\mathrm{b}}$ CEREGE-CNRS, Europôle Méditerranéen de l'Arbois, B.P.80, F13545 Aix-en-Provence Cedex 04, France \\ ${ }^{\mathrm{c}}$ CRA-CNRS, 250 Rue Albert Einstein, Sophia Antipolis, F06560 Valbonne, France \\ ${ }^{\mathrm{d}}$ C.A.P. Valence, UMR 5594 du CNRS, 4 place des Ormeaux, F26000 Valence, France
}

Received 28 January 2002

\begin{abstract}
The reliability of phytolith assemblage analysis for characterizing Mediterranean vegetation is investigated in this study. Phytolith assemblages are extracted from modern and buried Holocene soils from the middle Rhône valley (France). The relation between modern phytolith assemblages and the surrounding vegetation, as well as between fossil assemblages and contemporaneous vegetation, already reconstructed through other proxies, is discussed. We demonstrate that the main northwestern Mediterranean biomes are well distinguished by soil phytolith assemblage analysis. In particular, the density of pine and nonconiferous trees (densities expressed relatively to the grass cover) and the overall degree of opening of the vegetation appear well recorded by three phytolith indexes. North Mediterranean vegetation changes during the Holocene period, mainly tree line shifts, pine wood development and deforestation are poorly documented, due to the scarcity of proxy-preserving sites. Phytolith assemblage analysis of soils, buried soils, and sediments appears to be a promising technique to fill this gap.
\end{abstract}

(C) 2003 Elsevier Science (USA). All rights reserved.

Keywords: Phytolith; Pine; Paleoenvironment; Mediterranean area; Holocene, Buried soils

\section{Introduction}

The Mediterranean area is a transitional bioclimatic zone between temperate and tropical zones or between humid and arid zones. It is characterized by a staged vegetation (Ozenda, 1964) adapted to summer drought and cool winters. The Rhône valley is located on the French northern side of the Mediterranean basin, below the northern limit of the Mediterranean climatic zone, and at the boundaries of the Medio-European and Alpine climatic influences. This location makes the Rhône valley vegetation highly reactive to climatic changes and anthropic pressure. Moreover, a lot of archeological sites have recently been found in the Rhône valley, during excavations preparing the construction of the

* Corresponding author.

E-mail address: delhon@mae.u-paris10.fr (C. Delhon). new "TGV-Méditerranée" fast railway line, providing new environmental and archeological data.

The main vegetation changes in the northwestern Mediterranean area during the Holocene period, have been regionally traced through pollen and charcoal studies (De Beaulieu, 1977; Triat-Laval, 1978; Jalut, 1974; Vernet and Thiébault, 1987; Quezel, 1999). However, usual paleobotanical tools reach their limits in these sites.

The occurrence of pine in the Mediterranean vegetation is a marker of natural and anthropic stress. Pinus sylvestris is a species often considered as characteristic of mountain stage (Rameau et al., 1994), but its occurrence in southern areas (Tricastin, south Drôme) shows that edaphic factors are probably as determinant as climatic factors in its distribution. In case of weak human pressure, the pine timberline goes down when the climate gets cooler and when soils deteriorate. This colonizing species is a heliophyte and a 
pyrophyte, its spread being favored by fire, whether of natural or human origin (Pons and Thinon, 1987; Trabaud, 1989). As pine scatters great quantities of pollen, its variations in pollen spectra have often only regional scale significance and local variations under punctual pressure are not distinguished. Retracing more precisely the history of pine in this area would mean retracing fire history, in which both climate and human action have a great part to play (Barbero et al., 1990; Bradshaw, 1993; Berger and Thiébault, 2002).

Pollen-preserving sites are scarce, especially for recent Holocene times (Argant, 1990; Argant in Berger, 1996). Since they only trace woody plants, charcoal records show limitation in detecting forest/grassland shifts in response to human or natural stresses. Moreover, charcoal fragments from archeological sites allow a determination of collected fuel species, but they give no information about the spatial distribution of the various vegetal associations.

These limitations argue for the use of phytolith assemblage analysis as a complementary proxy. Phytolith assemblages, which are well preserved in oxidizing environments such as soils and buried soils, provide information on grass subfamilies (Twiss, 1992) and tree cover density (Alexandre et al., 1997, 1999; Barboni et al., 1999). Phytolith assemblage analysis has been used to trace with accuracy Holocene grassland dynamics and forest-grassland shifts in America, tropical Africa, and Asia (Kurman, 1985; Piperno, 1988; Tsutsuki et al., 1993; Inoue and Sase, 1996; Fredlund and Tieszen, 1997a,b; Alexandre et al., 1997, 1999; Barboni et al., 1999). Moreover, some studies have shown that pine species produce distinctive leaf phytoliths (Klein and Geis, 1978). At last, phytolith density (2.3), size $(2-50 \mu \mathrm{m}$ for morphotypes with taxonomic value), and deposition patterns (they simply fall on the ground without any anemophile or enthomophile transport) would argue in favor of distance transportation shorter than that for pollen.

Except for preliminary studies showing that phytoliths are well-represented in alluvial and colluvial deposits as well as in buried soils of the Rhône valley (Alexandre and Meunier, 1997; Delhon, 1998; Verdin et al., 2001), phytolith assemblage analysis has never been applied to the northern Mediterranean area.

Before attempting a reconstruction of vegetation changes, it is essential to investigate first the reliability of modern phytolith assemblages for the recording of vegetation sources. This preliminary study, even if dealing with a reduced number of samples, is the first step toward large paleoenvironmental phytolith-based reconstruction in the French Mediterranean area. Phytolith assemblages are extracted from modern soils and buried Holocene soils from the middle Rhône valley. The relationship between modern phytolith assemblages and the surrounding vegetation, or fossil phytolith assemblages and the contemporaneous regional vegetation, already reconstructed through other proxies, is discussed.

\section{The middle Rhône valley and the Valdaine basin}

The middle Rhône valley (Fig. 1) is located in southeastern France, between the Alps and the Massif Central. The average annual rainfall ranges from 800 to $1200 \mathrm{~mm}$. Precipitation is concentrated mainly over spring and autumn, while summer is affected by typical Mediterranean dryness. While the pluvio-nival river Rhône flows continuously, its tributaries dry out in summer.

The basins of the Roubion and Jabron rivers together form the Valdaine basin (Fig. 2), mainly composed of Quaternary alluvial formations in the center, of marls in the foothills, and of limestone and sandstone on the periphery (Berger, 1996).

Because of three climatic influences (Mediterranean, Medio-European and Alpine), of microclimatic conditions related to various topographies (plains, slopes, hills and terraces), and of strong and ancient human pressure, the middle Rhône valley landscape shows a mosaic of vegetation typical for the supra-Mediterranean stage (Ozenda, 1964, 1994). Forests are oak coppices, dominated by Quercus pubescens and pine woods (Pinus sylvestris). They usually contain an undergrowth of trees and grasses. Pine woods are the pioneer formations after fire in the area, when oak groves settle only secondly (Pons and Thinon, 1987; Trabaud, 1989). The grasslands result mainly from grazing on the slopes. They consist of grasses belonging to the Festucoideae subfamily of Poaceae and of grazing-resistant dicotyledons. Riverbanks are covered by dense but small riparian formations dominated by Alnus and Fraxinus in the plains and Populus on the foothills.

\section{Material and methods}

\subsection{Modern samples and local vegetation}

As a selective dissolution of phytoliths occurs in litter and soil, reference classification must be based on modern phytolith assemblages from soil humic horizons. Therefore, five soil samples were collected from five spots located under main supra-Mediterranean vegetation formations (Fig. 2).

Sample 1 comes from a sandy-loam alluvial soil (mollic fluvisol according to the American "Soil Taxonomy," Soil Survey Staff, 1975) located on the bank of the Vermenon river. This soil developed under a riparian forest dominated by Alnus and Fraxinus, with mainly Festucoideae grasses. This forest has been in place since the beginning of the 20th century which is the last period of deep incisions of riverbeds in the area.

Sample 2 comes from a loamy-clay brown to red calcic soil (luvic calcisol) located on a gravely Wurmian terrace of the Roubion river. This soil developed under a bicentennial oak grove (Quercus pubescens) with a clear grassy undergrowth layer (Festucoideae). 


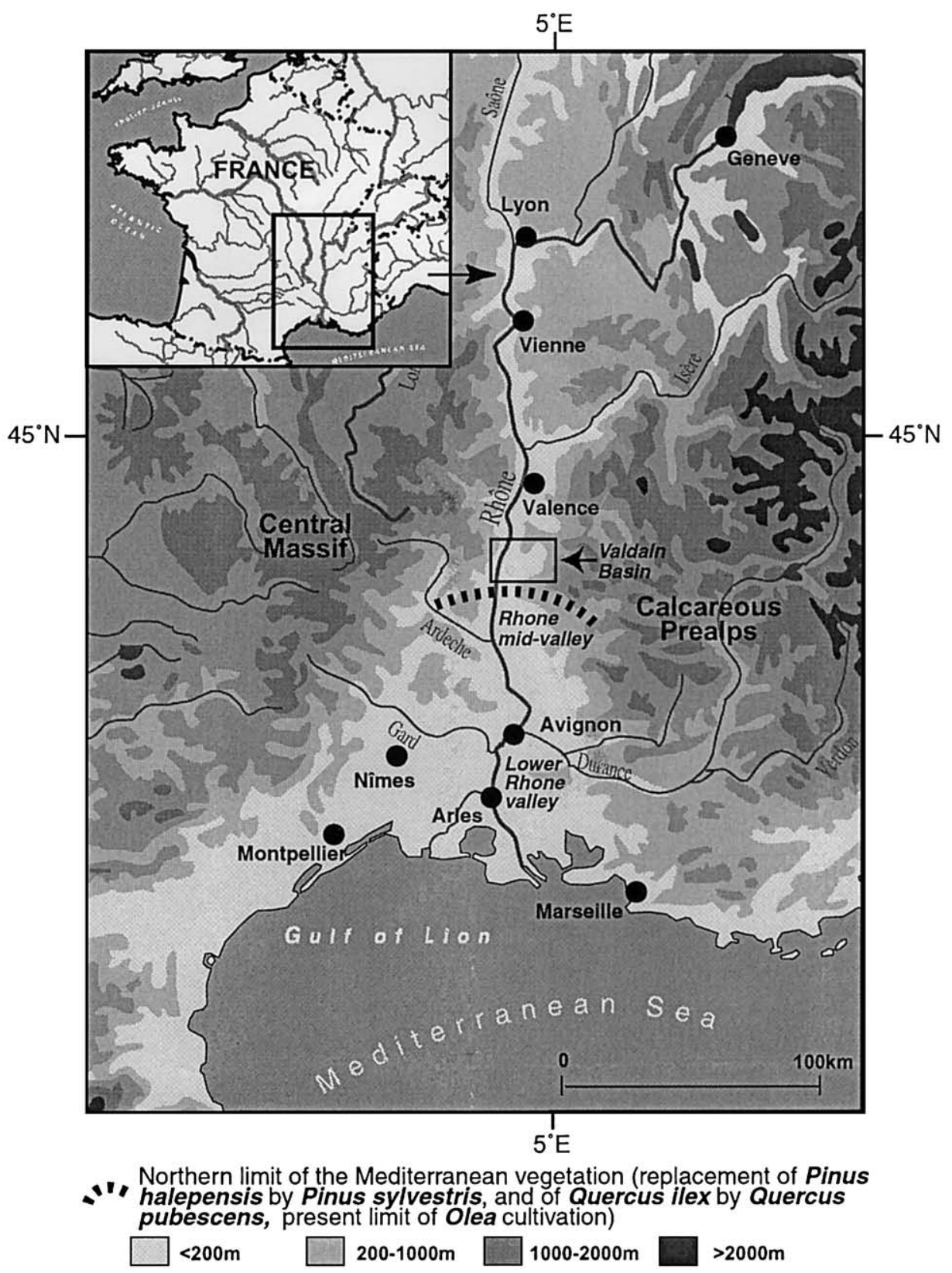

Fig. 1. Location of the middle Rhône valley: the Valdaine Basin and the North limit of the Mediterranean vegetation according to Ozenda (1994).

Sample 3 comes from a calcareous colluvial soil (rendzic leptosol) developed on recently stabilized Bad Lands on the marly south-orientated slopes of the Roynac hill. This soil developed under a grassland (mainly Festucoideae grasses), with scattered pines (Pinus sylvestris), that is not currently grazed. This soil should be younger than 100 years as photographs from the beginning of the 20th century show that rills widely marked the slopes, preventing soil development.

Sample 4 comes from a clay regosoil (calcaric regosol) located on the marly south-orientated slopes of the Roynac hill. This soil developed under a pine wood ( $P$. sylvestris) including some juniper (Juniperus communis) and a dense undergrowth grass layer (Festucoideae).
Sample 5 comes from a loamy and deep alluvial soil (eutritic fluvisol) located in the very low alluvial plain at the confluence of the Rhône and one of its tributaries, the Aygues river. This soil developed under a reed (Phragmites communis) and grass cover (Festucoideae) around a drainage ditch. As the last sediment deposition occurred during the 19th century, soil and herbaceous vegetation cannot be older than 150 years.

\subsection{Fossil samples and contemporaneous regional vegetation}

Six fossil samples are studied. They come from dated levels of pedosedimentary sequences of three different sites. 


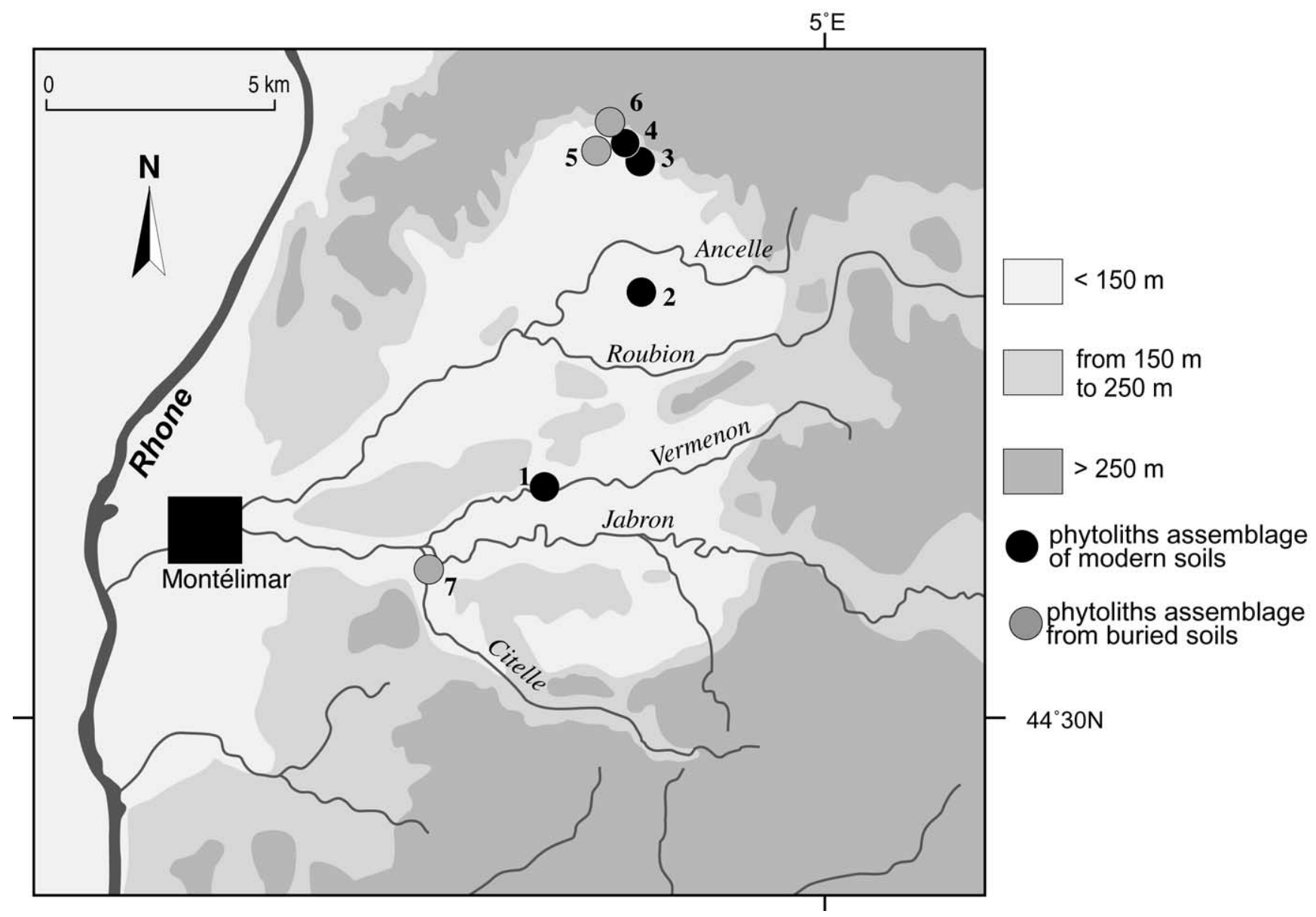

Fig. 2. The Valdaine Basin. Location of the main sampling sites: (1) river forest of Vermenon River at "les feuilles" site, (2) "Andran" forest on gravely Würmian terrace, $(3,4)$ south slope of marly hills of Roynac, (5) prehistoric settlement of Roynac-le-Serre, (6) prehistoric settlement of Roynac-les-Roches, and (7) prehistoric settlement of Espeluche-Lalo.

The levels formed during Holocene vegetation and morphoclimatic regional phases that are well documented (e.g., Triat-Laval, 1978; Vernet and Thiébault, 1987; Thiébault, 1988; Leveau and Provansal, 1993; Berger, 1996).

Sample 6 comes from a buried soil collected at Roynac-le-Serre (Fig. 2), on the northern slope of the Valdaine basin. It developed ca. $5685{ }^{14} \mathrm{C}$ yr B.P. (Table 1), during the Neolithic period of the area (around 6500 to $3800 \mathrm{yr}$ B.P.). This period is characterized by the development of agro-pastoral practices that have since contributed to the extension of the opening of Atlantic oak forests.

Samples 7a and 7b come from a black buried soil and an alluvial deposit located at Roynac-les-Roches (Fig. 2). They postdate an early Holocene layer $\left(9845 \pm 90{ }^{14} \mathrm{C}\right.$ yr B.P/

Table 1

Radiocarbon dates cited in the text

\begin{tabular}{|c|c|c|c|c|c|c|c|}
\hline Site & Reference & Structure & Phase & Material dated & Matrix/context & ${ }^{14} \mathrm{C}$ yr B.P. & $\begin{array}{l}\text { cal yr B.C.: } \\
2 \text { sigmas }\end{array}$ \\
\hline \multirow[t]{5}{*}{ Lalo } & AA 32644 & St. 8 & 17 & & Pit sediment & $6220 \pm 60$ & $5320-4990$ \\
\hline & AA32639 & St.73 & 10 & & Pit sediment & $6420 \pm 65$ & $5490-5260$ \\
\hline & AA 24897 & 42 & $9 b$ & Charcoal layer & Channel silt & $6705 \pm 60$ & $5720-5480$ \\
\hline & ETH 14840 & Drilling & $6 \mathrm{~b}$ & Charcoal layer & Alluvial palaeosoil & $6930 \pm 70$ & $5990-5660$ \\
\hline & AA 24898 & $64 \mathrm{~b}$ & 5 & Isolated charcoal & Alluvial palaeosoil & $7535 \pm 65$ & $6470-6230$ \\
\hline \multirow[t]{2}{*}{ Roynac-les-Roches } & ETH15401 & $\mathrm{C} 5,2,2$ & Ensemble 26 & Charcoal layer & Alluvial silt & $9785 \pm 80$ & $9500-8605$ \\
\hline & ETH1502 & $\mathrm{C} 25, \mathrm{~d} 2$ & Ensemble 26 & Charcoal layer & Alluvial silt & $9845 \pm 90$ & $9710-8735$ \\
\hline Roynac-le-Serre & ARC 1443 & St.A, soil S9 & Phase I2b & Charcoal cluster (hearth) & Alluvial silt & $5685 \pm 100$ & $4775-4360$ \\
\hline
\end{tabular}


$9785 \pm 80{ }^{14} \mathrm{C}$ yr B.P. Table 1$)$. They are related to the end of charcoal zonation phase 1 (from 11,000 to $8000 \mathrm{yr}$ B.P., Heinz and Thiébault, 1998), characterized by the dominance of P. sylvestris and Juniperus and to the end of Preboreal pollen subdivision (from 10,300 to $8900 \mathrm{yr}$ B.P., TriatLaval, 1978), characterized by the dominance of pine pollen. Moreover, pine microcharcoal has been identified in sample 7b (Thiébault, unpublished data). This pine-dominant open vegetation could be linked to cool and dry climatic conditions (Heinz and Thiébault, 1998). Pedological studies show a concentration of microcharcoal and secondary carbonate precipitation in these samples, which indicates a repetition of fire events and high evapotranspiration values (J.-L. Brochier, unpublished data). Epipalaeolithic and Mesolithic lithic items are associated with these pedosedimentary formations.

Samples 8a and 8b were collected in the low alluvial plain of the Citelle river, in the southern part of the Valdaine basin, at Espeluche-Lalo (Fig. 2). Sample 8a comes from a clayey-silted buried soil on the bank of a paleochannel. It is located between two sedimentary levels: the lower dated to $6705 \pm 60{ }^{14} \mathrm{C}$ yr B.P. (Table 1 ), and the upper is attributed to an early neolithic settlement $\left(6220 \pm 60{ }^{14} \mathrm{C}\right.$ yr B.P., Table 1). The studied part of this sequence was abruptly buried by sediments, due to slope instability ca. $6000{ }^{14} \mathrm{C} \mathrm{yr}$ B.P. (after $6930 \pm 70{ }^{14} \mathrm{C}$ yr B.P. and between $6420 \pm 65$ and $6220 \pm 60{ }^{14} \mathrm{C}$ yr B.P., Table 1). Microcharcoal fragments extracted from this sample were dicotyledons and belong mainly to Quercus sp. (Delhon, 1998). Sample 8b comes from a rubified buried soil developed on late glacial silts deposed on the Wurmian terrace of the Citelle river. It developed contemporaneously with a black buried soil dated to $7535 \pm 65{ }^{14} \mathrm{C}$ yr B.P. (Table 1). Microcharcoal fragments found in this sample have been identified mainly as monocotyledons and oak (Delhon, 1998). Sample 8c comes from an alluvial level without pedological features, on the bank of the Citelle river. Multiplicity of its possible vegetation sources will be taken into account when discussing its phytolith assemblage. These three samples are attributed to the pollen Atlantic subdivision (from ca. 8000 to $5000 \mathrm{yr}$ B.P.) and to the charcoal zonation phase 2 (from ca. 8000 to $6000 \mathrm{yr}$ B.P.), both characterized by a dominance of deciduous oak forest (Triat-Laval, 1978; Vernet and Thiébault, 1987; Heinz and Thiébault, 1998). These charcoal and pollen zonations point out the main vegetation trends, but the dominance of deciduous forests does not exclude the persistance of open or less densly wooded areas.

\subsection{Methods}

About $10 \mathrm{~g}$ of dry material was analyzed. Phytoliths were extracted from the 2- to $50-\mu \mathrm{m}$ fraction after calcium carbonate removal using $\mathrm{HCl}$, organic matter oxidation using $\mathrm{H}_{2} \mathrm{O}_{2}$, particle size fractionation, and densimetric separation in a $\mathrm{ZnBr}_{2}$ solution with a density of 2.35 (Kelly, 1990; Fredlund and Tieszen, 1994). Phytoliths were mounted on

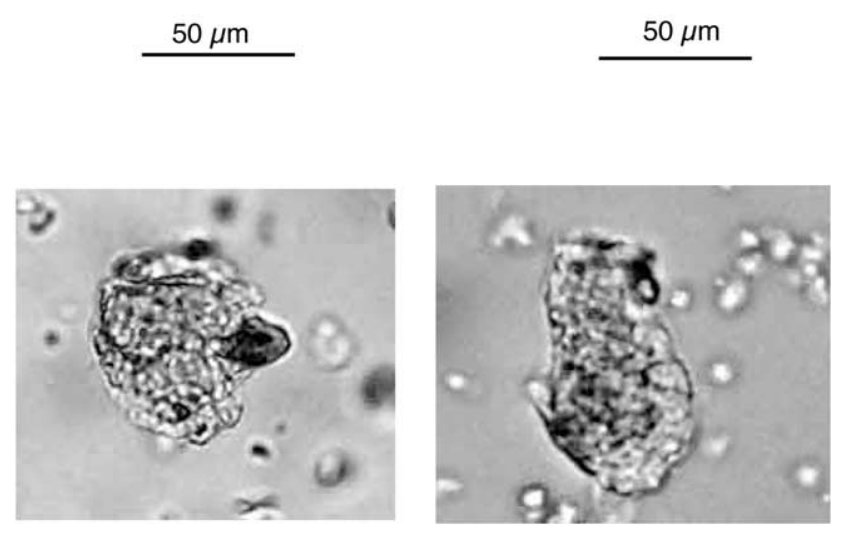

Fig. 3. Microphotographs of modern (left) and fossil (right) spherical-withsockets pine morphotype. Bar is $50 \mu \mathrm{m}$.

microscope slides in glycerol, which allows a three-dimensional observation. For each assemblage, more than 200 phytoliths of diameter greater than $5 \mu \mathrm{m}$ were counted, at $500 \times$ magnification.

Phytoliths were classified into nine morphotypes previously described (Twiss, 1992; Alexandre et al., 1997; Barboni et al., 1999; Runge, 1999): elongate, fan-shaped, pointshaped, rectangle-and-rondel, cross-and-dumbbell, smoothspherical, rough-spherical, cork-cell like, and silicified vessel. A tenth morphotype was observed. Since it has not been previously described, we named it "spherical-withsockets" (Fig. 3)

According to Twiss taxonomic classification of grass phytoliths (Twiss et al., 1969; Twiss, 1992), which was later improved by Mulholland (1992), elongate, point-shaped, and fan-shaped morphotypes are produced by the whole Poaceae family. Rectangle and rondel morphotypes are produced in great amount by the Festucoideae subfamily, while cross-and-dumbbell morphotypes are produced mainly by the Panicoideae subfamily. The main exceptions to this pattern, in the Mediterranean area, is the production by Stipa (Festucoideae) and Arundo donax (Arundinoideae, an introduced humid soils tall grass) of a small amount of cross-and-dumbbell morphotypes.

The rough-spherical morphotype is produced in dicotyledon wood (Geis, 1973; Bozarth, 1992; Scurfield et al., 1974; Laroche, 1976; Piperno, 1988). Some studies called it "circular rugose" (Piperno, 1988; Alexandre et al., 1997, 1999; Barboni et al., 1999), others "rough sphere" or "rough-spherical" (Kealhofer and Penny, 1998; Runge, 1999). In order to emphasize its three dimensional-shape, we opt for the latter nomenclature. Previous studies have shown that the ratio D/P equals to dicotyledon rough- and smooth-spherical morphotypes (D) versus Poaceae morphotypes $(\mathrm{P})$ in a phytolith assemblage was a reliable proxy for the tree cover density in intertropical areas (Alexandre et al., 1997, 1999; Barboni et al., 1999). Nevertheless, the dicotyledon tissue from which smooth-spherical phytoliths originate is still unknown. Silicified vessels are produced by 
dicotyledons (Piperno, 1988) but are scarcely found in soil assemblages (Alexandre et al., 1997). This is the reason why this morphotype is not taken into account when calculating $\mathrm{D} / \mathrm{P}$ ratio. The cork-cell-like morphotype is not used here for ecological interpretation as it is produced by numerous families (Ellis, 1979; Alexandre et al., 1997; Barboni et al., 1999). The unclassified group is composed of phytoliths showing no identifiable shape.

\section{Results}

Both modern and fossil phytolith assemblages show a significant proportion of unclassified phytoliths (from 16.5 to $53.2 \%$ of the phytolith sum). Classified morphotypes are similar in modern and fossil samples (except silicified vessels found in only one fossil assemblage, 7b) and are expressed (Table 2 and Fig. 4) as percentages of the sum of classified phytoliths. Confidence intervals have been calculated for each percentage. They can be broad (due to the great quantity of unclassified phytoliths in some assemblages), showing that low percentages must be cautiously discussed. A common point to all assemblages is the strong dominance of rectangle-and-rondel morphotypes, mainly produced by the Festucoideae subfamily, among the grass phytoliths with subfamily significance, while the cross-anddumbbell morphotypes never surpass $2.3 \%$ of the classified phytoliths, which is not an amount significantly different from zero.

\subsection{Phytolith assemblages from modern samples (Table}

2, Fig. 4)

The grassland phytoliths assemblage is characterized by the absence of dicotyledon phytoliths (rough- and smoothspherical) and the strong dominance of grass morphotypes $(93 \%)$. Among the latter, the only subfamily significance is borne by the rectangle-and-rondel morphotypes. The spherical-with-sockets morphotype accounts for $6.3 \%$.

The pine-wood phytolith assemblage shows the highest amount of spherical-with-sockets morphotype (20\%) among modern assemblages. Grass phytoliths are again abundant (78\%), while dicotyledon phytoliths, represented by the rough-spherical morphotype, do not exceed $1 \%$ (not significantly different of 0 ). This assemblage gives a $\mathrm{D} / \mathrm{P}$ ratio of 0.01 .

The oak grove phytoliths assemblage presents a high amount of dicotyledon phytoliths: $13.8 \%$, consisting of 12.5 and $1.4 \%$ of rough- and smooth-spherical morphotypes, respectively. However, grass phytoliths are still abundant $(85.7 \%)$. This assemblage gives a D/P ratio of 0.16 . Even if the cross-and-dumbbell morphotype reaches its maximum value in this assemblage, its occurrence remains nonsignificant with regard to the confidence interval. No sphericalwith-sockets phytoliths were counted in this assemblage.

The riparian-forest phytolith assemblage presents a pro- portion of dicotyledon phytoliths that is even higher than the previous assemblage (14.5\%), and the rough-spherical morphotype is better represented $(8.3 \%)$ than the smooth-spherical morphotype (6.2\%). Grass phytoliths are still abundant (78.2\%). The D/P ratio reaches 0.19 . The spherical-withsockets morphotype does not reach $1 \%$.

As for the grassland assemblage, the phytolith assemblage from the reed formation is characterized by a strong dominance of grass phytoliths $(97 \%)$. Some cross-anddumbbell morphotypes are represented, but not in statistically representative amounts (1.5\%). Dicotyledon phytoliths (here smooth-spherical morphotype) reach only $2.5 \%$. Thus, this assemblage shows a $\mathrm{D} / \mathrm{P}$ ratio of 0.03 only. The spherical-with-sockets morphotype is not represented.

\subsection{Phytolith assemblages from archeological samples}

The phytolith assemblages of samples $7 \mathrm{a}$ and $7 \mathrm{~b}$ were produced and deposited contemporaneously with the end of postglacial pine dominance. Both samples are characterized by the two highest proportions of the spherical-with-sockets morphotype (29.8 and $25.9 \%$, respectively). Grass phytoliths account for 59.5 and $52.8 \%$, respectively, and their spherical dicotyledon phytoliths for 1.37 and 0 . However, sample $7 \mathrm{~b}$ is the only one showing a significant proportion of dicotyledon silicified vessels $(7.5 \%)$.

The phytolith assemblage of sample 6 was deposited during a period of expansion of agro-pastoral practices, whose effects on the vegetal landscape are still under discussion (Beeching et al., 2000). Grass phytoliths are numerous $(87 \%)$; dicotyledon phytoliths account for $5 \%$, equally divided among rough- and smooth-spherical morphotypes. All the grass phytoliths with subfamily significance come from the Festucoideae subfamily. No spherical-with-sockets phytoliths have been encountered.

Phytolith assemblages 8a, 8b, and 8c were deposited during the Atlantic period of oak forest development. Assemblages $8 \mathrm{a}$ and $8 \mathrm{~b}$ show the two highest D/P ratios: 0.29 and 0.44 , respectively. Dicotyledon phytoliths account for 21.47 and $28.48 \%$, respectively, including both rough- and smooth-spherical morphotypes. Grass phytoliths represent 72.8 and $65.2 \%$, respectively, and are dominated by rectangles-and-rondels. Cross-and-dumbbells morphotypes can be due either to the presence of Stipa (Festucoidae) or of some Panicoidae (e.g., Setaria sp.). The spherical-with-sockets morphotype is absent from assemblage $8 \mathrm{a}$ and accounts for $3.5 \%$ in assemblage $8 \mathrm{~b}$.

Assemblage $8 \mathrm{c}$ is extracted from an alluvial layer. The difference of this assemblage compared to $8 \mathrm{a}$ and $8 \mathrm{~b}$ assemblages lies in a far lower D/P ratio $(0,10)$. Dicotyledon phytoliths account for $8.3 \%$, including smooth-spherical (2.9\%) and rough-spherical (5.4\%) morphotypes. Grass phytoliths account for $84.3 \%$. The spherical-with-sockets morphotype represents $3.9 \%$. 
Table 2

Abundance of the different phytolith morphotypes in modern and fossil assemblages

\begin{tabular}{|c|c|c|c|c|c|c|c|c|c|c|c|c|c|}
\hline \multirow{2}{*}{$\begin{array}{l}\text { Hypothesis on } \\
\text { taxonomic significance: } \\
\text { Morphotypes: }\end{array}$} & & \multicolumn{3}{|l|}{ Non used } & \multirow{2}{*}{$\begin{array}{l}\text { Pinaceae } \\
\text { Spherical } \\
\text { with } \\
\text { sockets }^{\text {b }}\end{array}$} & \multicolumn{2}{|l|}{ Dicots } & \multicolumn{3}{|l|}{ Poaceae } & \multicolumn{3}{|c|}{ Ratios } \\
\hline & & Unclassified $^{\mathrm{a}}$ & $\begin{array}{l}\text { Cork-cells } \\
\text { like } \\
\text { phytoliths }^{\mathrm{b}}\end{array}$ & $\begin{array}{l}\text { Silicified } \\
\text { vessels }^{\text {b }}\end{array}$ & & $\begin{array}{l}\text { Smooth } \\
\text { spherical }^{\text {b }}\end{array}$ & $\begin{array}{l}\text { Rough } \\
\text { spherical }^{\text {b }}\end{array}$ & $\begin{array}{l}\text { Elongate, } \\
\text { point and } \\
\text { fan-shaped }^{\text {b }}\end{array}$ & $\begin{array}{l}\text { Rectangle } \\
\text { and } \\
\text { rondel }^{\text {b }}\end{array}$ & $\begin{array}{l}\text { Cross and } \\
\text { dumbbell }^{\text {b }}\end{array}$ & $\mathrm{D} / \mathrm{P}^{\mathrm{c}}$ & $\mathrm{Pi} / \mathrm{P}^{\mathrm{d}}$ & $\begin{array}{l}\mathrm{T} / \mathrm{P}^{\mathrm{e}} \\
=(\mathrm{D}+\mathrm{Pi}) / \mathrm{P}\end{array}$ \\
\hline \multicolumn{14}{|l|}{ Modern samples } \\
\hline Riparian forest & 1 & 35 & 6.2 & 0 & 0.5 & 6.2 & 8.3 & 19.7 & 58.6 & 0 & 0.19 & 0 & 0.19 \\
\hline Oak grove & 2 & 16.5 & 0 & 0 & 0 & 12.4 & 1.4 & 45.6 & 37.8 & 2.3 & 0.16 & 0 & 0.16 \\
\hline Grassland & 3 & 41.1 & 0.5 & 0 & 6.3 & 0 & 0 & 14.9 & 78.4 & 0 & 0 & 0.07 & 0.07 \\
\hline Pine wood & 4 & 35.6 & 1 & 0 & 20 & 1 & 0 & 5.4 & 72.7 & 0 & 0.01 & 0.26 & 0.27 \\
\hline $\begin{array}{l}\text { Reed formation } \\
\text { Fossil samples }\end{array}$ & 5 & 36.7 & 0.5 & 0 & 0 & 2.5 & 0 & 20 & 75.5 & 1.5 & 0.03 & 0 & 0.03 \\
\hline $\begin{array}{l}\text { Roynac-le-Serre } \\
\quad \text { (grassland expansion) }\end{array}$ & 6 & 80 & 8 & 0 & 0 & 2.5 & 2.5 & 71 & 16 & 0 & 0.06 & 0 & 0.06 \\
\hline \multirow{2}{*}{$\begin{array}{l}\text { Roynac-les-Roches } \\
\text { (pine forest expansion) }\end{array}$} & $7 \mathrm{a}$ & 27.4 & 5.2 & 0 & 29.8 & 0 & 1.4 & 42.1 & 17.4 & 0 & 0.02 & 0.50 & 0.52 \\
\hline & $7 b$ & 53.2 & 13.9 & 7.5 & 25.9 & 0 & 0 & 45.3 & 7.5 & 0 & 0 & 0.49 & 0.49 \\
\hline \multirow{3}{*}{$\begin{array}{l}\text { Espeluche-Lalo } \\
\quad \text { (oak wood expansion) }\end{array}$} & $8 \mathrm{a}$ & 46.5 & 4.7 & 0 & 0 & 5 & 16.4 & 34.6 & 38.3 & 0 & 0.29 & 0 & 0.29 \\
\hline & $8 \mathrm{~b}$ & 41.7 & 2 & 0 & 3.5 & 25.9 & 3 & 29.3 & 35.3 & 0.5 & 0.44 & 0.05 & 0.50 \\
\hline & $8 \mathrm{c}$ & 37 & 3.4 & 0 & 3.9 & 2.9 & 5.4 & 16.7 & 67.7 & 0 & 0.10 & 0.05 & 0.15 \\
\hline
\end{tabular}

${ }^{a}$ In percentage of the phytolith sum (all the phytoliths observed are taken into account).

${ }^{\mathrm{b}}$ In percentage of the classified phytolith sum (only significant morphotypes are taken into account).

${ }^{c}$ Ratio of Dicotyledon versus Poaceae phytoliths: D/P

${ }^{\mathrm{d}}$ Ratio of Pinaceae versus Poaceae phytoliths Pi/P

${ }^{\mathrm{e}}$ Ratio of Tree versus Poaceae phytoliths: T/P 


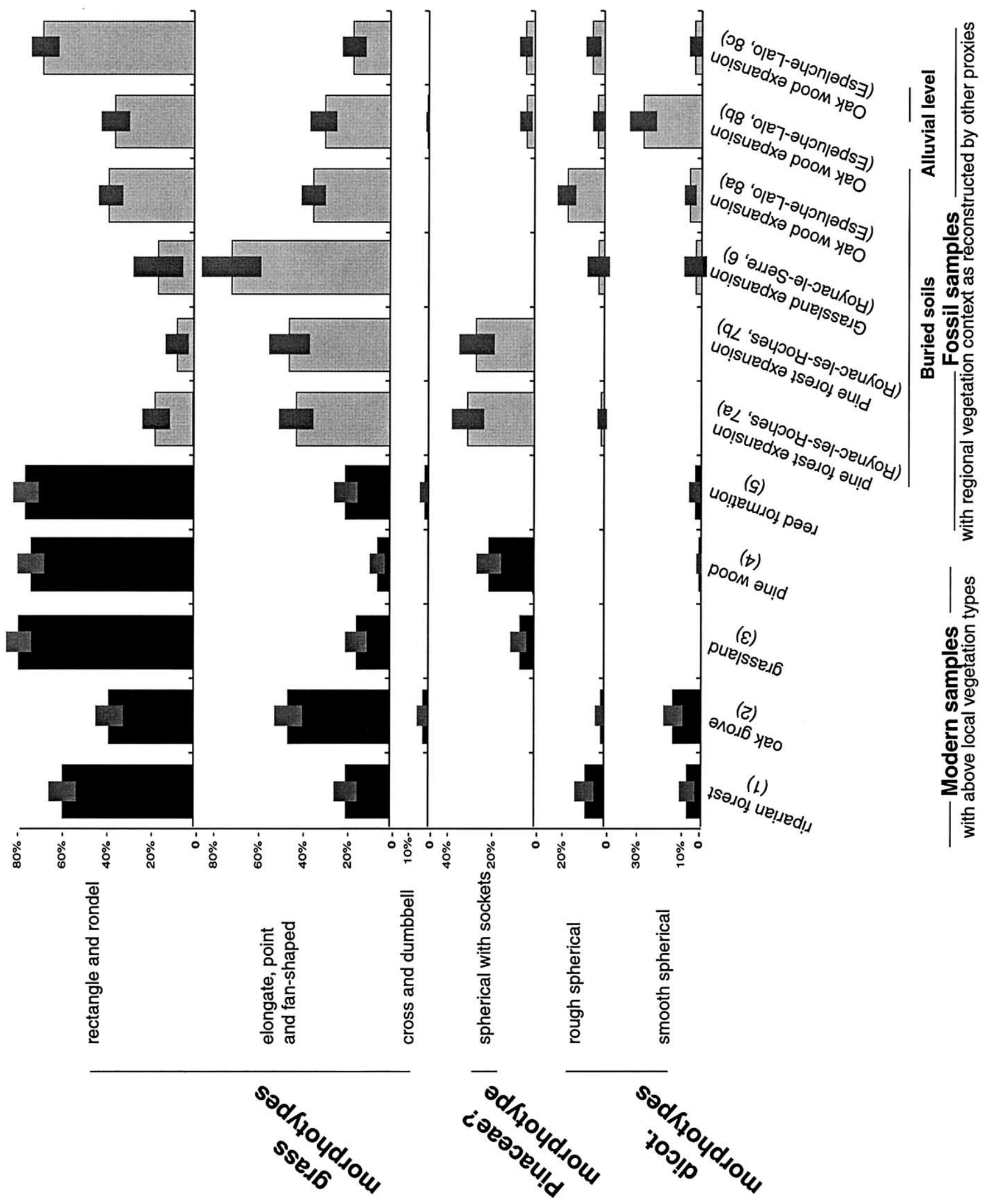




\section{Discussion}

\subsection{Toward a new phytolith index tracing broad-leaved tree cover density for the northwest Mediterranean area}

The D/P ratio equal to dicotyledon rough- and smoothspherical morphotypes (D) versus Poaceae morphotypes (P) proved to be a reliable proxy of the tree cover density in tropical areas (Alexandre et al., 1997, 1999; Barboni et al., 1999).

In the present case, where gymnosperms can be well represented, investigation of relationships between D/P ratios and vegetation sources demonstrate that this phytolith index is a proxy of the broad-leaved tree cover density. Two types of assemblages can be distinguished by their D/P ratio (Table 1 and Fig. 5): The first shows D/P ratios higher than 0.1 . It includes modern assemblages 1 and 2 collected under dicotyledon forests and fossil assemblages $8 \mathrm{a}$ and $8 \mathrm{~b}$ contemporaneous with oak forest development. Thus, high D/P ratios accurately record high broad-leaved tree cover density.

The second group shows $\mathrm{D} / \mathrm{P}$ ratios far lower than 0.1 . It includes modern assemblage 3 produced by grassland, modern assemblage 4 produced by pine wood, modern assemblage 5 related to reed formations, fossil assemblage 6 related to the Neolithic period, and fossil assemblage 7a related to the pine forest expansion phase. Low D/P ratios accurately trace a low representation of dicotyledon trees. Four assemblages among the five showing low D/P ratios contain statistically nonreliable proportions of dicotyledon phytoliths, which prevent more precise comparisons between them. Fossil assemblage 8c, recovered from an alluvial level contemporaneous with the oak forest development, shows a $\mathrm{D} / \mathrm{P}$ ratio of 0.10 . Because it has not been extracted from a buried soil, this assemblage is discussed below.

The $\mathrm{D} / \mathrm{P}$ value of 0.1 , used here as a lower limit to distinguish dicotyledon forest records from other records, is far lower than the previously published values of 7.0, 0.6, and 1.5, respectively, related to a semi-evergreen forest in Congo (Alexandre et al., 1997), a riparian forest in Ethiopia (Barboni et al., 1999), and a transition zone between a tree savana and a mesophytic forest in Brazil (Alexandre et al., 1999). Tropical broad-leaved forests are denser than Mediterranean forests and the D/P ratio appears accurate enough to express this difference.

\subsection{Toward a new phytolith index of pine cover density for the northwest Mediterranean area}

Phytolith assemblages deposited under modern pine woods and during the Holocene pine expansion (assem- blages $7 \mathrm{a}$ and $7 \mathrm{~b}$ ) are characterized by a high representation of the spherical-with-sockets morphotype, while this morphotype is absent or scarcely represented in other assemblages. The following discussion assesses the reliability of this morphotype for tracing pine cover.

Pine phytoliths have already been observed, in situ, in needles (Klein and Geis, 1978; Bartoli, 1981). However, observation scales varied and the spherical-with-sockets morphotype could not be surely recognized from published pictures. Our investigation of gymnosperm needle phytoliths from the CEPAM-CNRS (Sophia Antipolis, France) reference collection showed that a Pinaceae, Picea abies, produces phytoliths presenting a spherical shape and bearing a special honeycombed ornamentation, similar to the spherical-with-sockets morphotype present in our modern and fossil assemblages (Fig. 3). Picea abies is not represented in the area, but pine is a close relative. However, redundancy is inherent to phytolith production and there is no evidence that gymnosperms other than Pinaceae may not produce the same spherical-with-sockets morphotype. In the northwest Mediterranean area, pine (especially P. sylvestris for the supra-Mediterranean stage) and juniper ( nis) have dominated the gymnosperm population since the beginning of Holocene. We investigated needles of J. communis, but no typical phytoliths were found. Since past and modern formations dominated by pine produce high proportions of the spherical-with-sockets morphotype, we conclude that this morphotype reveals the presence of pine in Holocene past and modern vegetation of the northwest Mediterranean area.

The Pi/P ratio of Pinaceae spherical-with-sockets phytoliths $(\mathrm{Pi})$ versus Poaceae phytoliths $(\mathrm{P})$ reaches values higher than 0.26 for assemblages produced by modern pine woods and during the Holocene pine expansion phase, while it does not reach 0.1 for the other assemblages. Thus, the $\mathrm{Pi} / \mathrm{P}$ ratio appears to be a new and reliable proxy of pine cover density for Holocene vegetation reconstruction in the Rhône valley.

In order to apply this new pine proxy to other areas, further investigations of phytolith production of various pine species and other gymnosperms are needed. This can be achieved by analyzing phytolith assemblages from soils of various modern gymnosperm formations.

\subsection{Toward a new phytolith index tracing tree cover density for the north-west Mediterranean area}

The northwestern Mediterranean area has experienced phases of forest opening since the beginning of Holocene, due either to climatic conditions or to human pressure, as shown by charcoal analysis (Vernet and Thiébault, 1987; Heinz and Thiébault, 1998). However, charcoal analysis is

Fig. 4. Phytolith percentage diagram of modern (black bars) and fossil (grey bars) Rhône valley samples (with $95 \%$ confidence intervals: $\pm 1.96 \sqrt{ }\left(p_{o} q_{o}\right)$ represented with dark grey bars). 

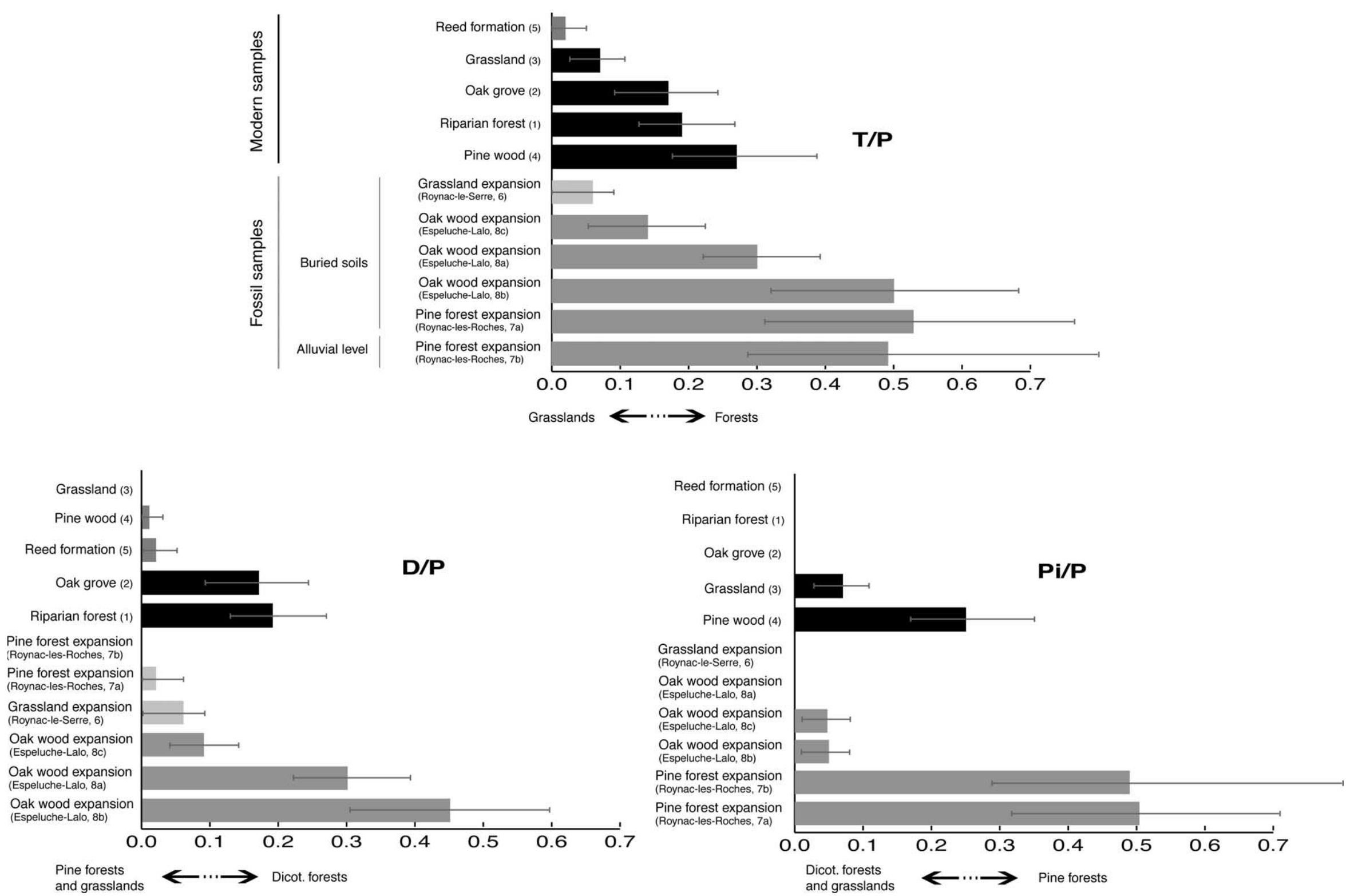

Fig. 5. Graphic representation of T/P (Tree phytoliths versus Poaceae phytoliths) and of its two components, D/P (Dicotyledon phytoliths versus Poaceae phytoliths) and Pi/P (Pinaceae phytoliths versus Poaceae phytoliths) ratios, showing the boundaries between forests and grasslands, between pine forests and other formations, and between dicotyledon forests and other formations. Modern samples are represented with black bars and fossil samples with grey bars; in these two pools of samples, the ratios calculated from nonsignificant percentages are represented with lighter bars (T/P, sample 6 and reed formation; D/P, samples 6 , 7a, pine wood, and reed formation) 
unsuitable for detecting grass cover. Quantifying the degree of opening of the vegetation cover appears possible, using a new phytolith index, T/P, corresponding to the ratio of characteristic tree phytoliths, including angiosperm and gymnosperm species $(\mathrm{T})$, versus Poaceae phytoliths $(\mathrm{P})$ : T/P $=\mathrm{D} / \mathrm{P}+\mathrm{Pi} / \mathrm{P}$.

Among our assemblages two groups are distinguished (Table 1, Fig. 5). Assemblages produced by forests show a T/P ratio higher than 0.15 (pine wood (4), 0.27; oak grove (2), 0.16; riparian forest (1), 0.19; Preboreal pine expansion (7a and 7b), 0.52 and 0.49; Atlantic oak wood expansion (8a and $8 \mathrm{~b}$ ), 0.29 and 0.50 ), while assemblages produced by grasslands show a T/P ratio lower than 0.1 (grassland (3), 0.07 ; reed formation (5), 0.03 ; local forest regression (6), $0.06)$. The vegetation density variations appear well-mirrored by this T/P ratio. Even if more modern and fossil samples must be processed in order to validate the boundary values proposed here for each ratio, this demonstrates that the T/P phytolith index can be used as a quantitative proxy of the opening of the northwestern Mediterranean vegetation.

All of the three indexes proposed here have shown accuracy in describing Mediterranean vegetation, but further studies are still needed in order to increase the number of assemblages analyzed and to decrease confidence intervals.

\subsection{Space scale representation of phytolith assemblages from buried soils and alluvial deposit}

The $\mathrm{Pi} / \mathrm{P}, \mathrm{D} / \mathrm{P}$, and $\mathrm{T} / \mathrm{P}$ ratios from the five modern phytolith assemblages studied here reflect the pine representation, the broad-leaved tree representation, and the opening degree of the top vegetation formations. Each related vegetation patch is not older than 200 years and does not extend over large areas. Thus, the five phytolith assemblages, extracted from soil humic horizons, record with accuracy the modern local vegetation. This result corroborates the local representativeness of phytolith assemblages from soils, as already suggested by Bartoli and Guillet (1977).

Charcoal and pollen records from distant sites (TriatLaval, 1978; Planchais, 1985; Vernet and Thiébault, 1987; Heinz and Thiébault, 1998) show that the Mediterranean vegetation has always had a mosaic pattern, even if a strong increase in heterogeneity, due to agro-pastoral practices, is recorded from around $6000{ }^{14} \mathrm{C}$ yr B.P. (Vernet et al., 1987). Phytolith assemblages from buried soils from similar or close (about $10 \mathrm{~m}$ ) locations and dated to the same regional vegetation phase $7 \mathrm{a}$ and $7 \mathrm{~b}$ and $8 \mathrm{a}$ and $8 \mathrm{~b}$ give close phytolith indexes, in agreement with regional vegetation trends (pine forest development and oak forest development, respectively). However, assemblage $7 \mathrm{~b}$ also shows a high amount of silicified vessels produced by dicotyledons that were never found in other assemblages. This can be explained by a local vegetation feature, as the local presence of dicotyledons within the regional pine formations. Assem- blage $7 \mathrm{~b}$ comes from an alluvial level, and the vegetation heterogeneity is thus better recorded in this assemblage than in soil samples. Assemblages 6 and 8, both dated to the Atlantic period, record a grassland settlement and a broadleaved forest, respectively. While assemblages $8 \mathrm{a}$ and $8 \mathrm{~b}$ have been collected in the very low Citelle River alluvial plain, assemblage 6 comes from the slopes of the Roynac hill. The topographic heterogeneity may explain the heterogeneity of the vegetation's responses to natural fires and anthropic stress. This shows that phytolith assemblage analysis is accurate for reconstructing local variations of the vegetation, due either to local unstability of the ecosystem or to local pressure (especially human), inside the regional pattern given by pollen and charcoal studies.

Assemblage 8c, also contemporaneous with the Atlantic oak forest development, shows a middle $\mathrm{D} / \mathrm{P}$ ratio and significant amounts of pine and grass phytoliths. Since it is recovered from an alluvial level, it includes phytoliths originating from all the different patches of vegetation covering the Citelle basin at this time. Oak forest, scattered pine stands remaining from the previous phase or developed after fire, and opening areas linked to human disturbance could cohabit on the slopes, while the riverbanks would have been covered by riparian formations.

These results suggest that fossil phytolith assemblages extracted from buried soils record the vegetation features at a local scale, while phytolith assemblages from sedimentary layers are likely to reflect the regional mosaic of vegetation.

\section{Conclusion}

Phytolith assemblage analysis is applied to a north Mediterranean environment. Although the number of processed samples is low, our results show that phytolith assemblage analysis is accurate for tracing local vegetation features otherwise unrecognizable by other proxies. Unlike pollen, phytolith assemblages are well preserved in soils and buried soils and give a local scale record. Unlike charcoal, phytolith assemblages give quantitative information on the degree of opening of the recorded vegetation. Phytolith assemblage analysis is consequently complementary to pollen and charcoal studies.

Three phytolith indexes have been displayed as accurate tracers of the Rhône valley vegetation features. D/P ratio, corresponding to the ratio of dicotyledon spherical morphotypes (D) versus Poaceae phytoliths (P), traces broad-leaved tree cover density. Pi/P ratio corresponding to the ratio of pine spherical with sockets morphotype $(\mathrm{Pi})$ versus Poaceae phytoliths $(\mathrm{P})$, records pine cover density. T/P ratio, which is the sum of $\mathrm{Pi} / \mathrm{P}$ and $\mathrm{D} / \mathrm{P}$ ratios, records the overall tree $(\mathrm{T})$ cover density or opening degree of the vegetation. The use of these three ratios in fossil phytolith sequences would greatly improve reconstruction of pine timberline shifts, oak forest development, and spatial and temporal variations of 
the forest's opening in the northwestern Mediterranean region.

The main changes of the northwest Mediterranean vegetation during the Holocene period were due to climatic stress and human disturbance. Distinguishing their respective influence during the late Prehistory is still one of the main challenges for Mediterranean paleoenvironmental research. These first results show that phytolith assemblage analysis is a promising tool in this field.

However, in order to extend these results to other Mediterranean areas, correlation between values of soil phytolith indexes and both floristic and physiognomic data of the various vegetation sources are required.

\section{Acknowledgments}

This study was done at CEREGE, Aix-en-Provence (France), in the framework of C. Delhon's DEA. It was supported by the French new "TGV-Méditerranée" fast railway and by the French program "Paléoenvironnement, évolution des hominidés-Hydrosystémes continentaux, paléoenvironnements et anthropisation dans le bassin-versant méditerranéen du Rhône depuis le Tardiglaciaire" (J.F. Berger and M. Provansal, dir.). We thank T. Odiot (S.R.A. Languedoc, coordinator of the archeological excavations on the TGV-Lines), V. Bel (AFAN Méditerranée), and the archeologists who excavated the archeological sites on the TGV line (mainly A. Beeching and J. Vital (CAP Valence/ CNRS) for the present paper). We also express a special thanks to P. Verdin (CEPAM-CNRS, Sophia Antipolis, France) for providing reference slides. We are also grateful to P. Anderson and M. Brooks for correcting the manuscript.

\section{References}

Alexandre, A., Meunier, J.D., 1997. Apports des travaux archéologiques du TGV-Méditerranée en vallée du Rhone à l'histoire des paysages et du climat, des temps glaciaires à nos jours. L'Analyse Phytolithique. CEREGE internal report.

Alexandre, A., Meunier, J.D., Lézine, A.M., Vincens, A., Schartz, D., 1997. Phytoliths: indicators of grasslands dynamics during the late Holocene in intertropical Africa. Paleogeography Paleoclimatology Paleoecology 136, 213-229.

Alexandre, A., Meunier, J.-D., Mariotti, A., Soubies, F., 1999. Late Holocene phytoliths and carbon-isotope record from a latosol at Salitre, south-central Brazil. Quaternary Research 51 (2), 187-194.

Argant, J., 1981. Climat et environnement au Quaternaire dans le bassin du Rhone d'après les données palynologiques. Document du Laboratoire de Géologie de Lyon 111.

Barbero, M., Loizel, R., Quezel, P., 1990. Méditerranée: Les incendies et l'évolution des forêts. La Recherche 22, 1154.

Barboni, D., Bonnefille, R., Alexandre, A., Meunier, J.D., 1999. Phytoliths as paleoenvironemental indicator at the Middle Awash hominid site, Ethiopia. Paleogeography, Paleoclimatology, Paleoecology 152, 87100.
Bartoli, F., 1981. Le cycle biogéochimique du silicium sur roche acide. Application à deux systèmes forestiers tempérés (Vosges). Thesis, Université Nancy I, France.

Bartoli, F., Guillet, B., 1977. Etude comparée des diagrammes phytolithiques et polliniques d'un podzol des Vosges gréseuses. Comptes Rendus de l'Académie des Sciences de Paris 284D, 353-356.

Beeching A., Berger, J.F., Brochier, J.L., Ferber, F., Helmer, D., Sidi Maamar, H., 1977. Chasséens: agriculteurs ou éleveurs, sédentaires ou nomades? Quels types de milieux, d'économies, de sociètès? Actes des $3^{\text {èmes }}$ rencontres méridionales de préhistoire récente, Toulouse 1998.

Berger, J.F., 1977. Le cadre paléogéographique des occupations du bassin du valdainais (Drôme) à l'Holocène. Thesis, Université Paris I, France.

Berger, J.-F., Thiebault, S., 2002. The study and significance of charcoal as an indication of ancient fire: an application to the middle Rhône valley (France), in: Thiébault, S. (Ed.), Charcoal analysis: Methodological Approaches, Palaeoecological Results and Wood Uses. Proceedings of the Second Meeting of Anthracology, Paris, September 2000, Archaeopress, 25-41.

Bozarth, S.R., 1992. Classification of opal phytoliths formed in selected dicotyledons native to the great plains, in: Rapp, G., Mulholland, S.C. (Eds.), Phytolith Systematics: Emerging Issues, Plenum Press, New York, pp. 193-214.

Bradshaw, R., 1993. Forest response to Holocene climatic change: equilibrium or non-equilibrium, in: Chamber, F.M. (Ed.), Climatic Change and Human Impact on the Landscape, Chapman and Hall, London, pp. $57-65$.

De Beaulieu, J.L., 1977. Contribution pollenanalytique à l'histoire Tardiglaciaire et Holocène de la végétation des Alpes méridionnales françaises. Thesis, Université d'Aix-Marseille III, France.

Delhon, C., 1998. "Identification et interprétation de cortèges phytolithaires et anthracologiques à partir de séquences pédosédimentaires de milieux fluviaux en moyenne vallée du Rhône (Holocène)-Apport à la connaissance de l'anthropisation du milieu." DEA, Université de Franche-Comté, France.

Ellis, R.P., 1979. A procedure for standardising comparative leaf anatomy in the Poaceae. II: The epidermis as seen in surface view. Bothalia 12 (4), 641-671.

Fredlund, G., Tieszen, L.T., 1994. Modern phytolith assemblages from the North American Great Plains. Journal of Biogeography 21, 321-335.

Fredlund, G., Tieszen, L., 1997a. Calibrating grass phytoliths assemblages in climatic terms: application to late Pleistocene assemblages from Kansas and Nebraska. Palaeogeography, Palaeoclimatology, Palaeoecology 136, 199-211.

Fredlund, G., Tieszen, L., 1997b. Phytolith and carbon evidence for late Quaternary vegetation and climate change in the southern Black Hills, South Dakota. Quaternary Research 47, 206-217.

Geis, J.W., 1973. Biogenic silica in selected species of deciduous angiosperms. Soil Science 116 (2), 113-119.

Heinz, C., Thiébault, S., 1998. Characterization and palaeoecological significance of archaeological charcoal assemblages during late and postglacial phases in southern France. Quaternary Research 50, 56-68.

Inoue, K., Sase, T., 1996. Paleoenvironmental history of post-Toya ash tephric deposits and paleosols at Iwate volcano, Japan, using eolian dust content and phytolith composition. Quaternary International 3436, 206-217.

Jalut, G., 1974. "Evolution de la végétation et variations climatiques durant les quinze derniers millénaires dans l'extrémité orientales des Pyrénées." Thesis, Université de Toulouse, France.

Kealhofer, L., Penny, D., 1998. Fourteen thousand years of environmental change in northeast Thailand. Review of Palaeobotany and Palynology 103, 83-93.

Kelly, E.F., 1990. "Method for extracting opal phytoliths from soils and plant material." Internal Doc., Dep. Agronomy, Colorado state university, Fort Collins.

Klein, R.L., Geis, J.W., 1978. Biogenic silica in the Pinaceae. Soil Science 123 (3), 145-156. 
Kurman, M.H., 1985. An opal phytoliths and palynomorph study of extant and fossil soils in Kansas (USA). Palaeogeography, Palaeoclimatology, Palaeoecology 49, 217-235.

Laroche, J., 1976. La silice et les plantes supérieures. Revue de Cytologie et de Biologie Végétale 40, 15-45.

Leveau, P., and Provansal, M., 1993. "Archéologie et Environnement: de la Sainte Victoire aux Alpilles." Publications Université de Provence.

Mulholland, S.C., 1992. A morphological classification of grass silica bodies, in: Rapp, G., Mulholland, S.C. (Eds.), Phytolith Systematics. Emerging Issues, Plenum Press, New York, pp. 129-147.

Ozenda, P., 1964. "Biogéographie végétale.” Douin, Paris.

Ozenda, P., 1994. "Végétation du continent européen." Delachaux et Niestlé, Paris.

Piperno, D.R., 1988. Phytolith Analysis. An Archaeological and Geological Perspective. Academic Press, New York.

Planchais, N., 1985. Analyses polliniques du remplissage holocène de la lagune de Cnet (plaine du Roussillon, Pyrénées orientales), in: De Beaulieu, J.L., Pons, A. (Eds.), Palaeohydrological Changes in the Temperate Zone in the Last 15000 Years, Ecologia Mediterranea XI (1), 117-127.

Pons, A., Thinon, M., 1987. The role of fire from palaeoecological data. Ecologia Mediterranea XIII (4), 3-11.

Quezel, P., 1999. Les grandes structures de végétation en région Méditerranéenne: facteurs déterminants dans leur mise en place post-glaciaire. Geobios 32 (1), 19-32.

Rameau, J.C., Mansion, D., Dumé, G., 1994. Flore Forestièere Française, guide écologique illustré. Tome 1: Plaines et Collines. Institut pour le développement forestier, Paris.

Runge, F., 1999. The opal phytolith inventory of soils in Central Africa. Quantities, shapes, classification and spectra. Review of Palaeobotany and Palynology 107, 23-53.

Scurfield, G., Anderson, C.A., Segnit, E.R., 1974. Silica in woody stems. Australian Journal of Botany 22, 211-229.
Soil Survey Staff, 1975. "Soil Taxonomy." U.S. Dept. Agric. Hb. 436, Washington D.C

Thiébault, S., 1988. "L’homme et le milieu végétal: analyses anthracologiques de six gisements des Préalpes au Tardi- et au Postglaciaire." Documents de 1'Archéologie Française 15.

Trabaud, L., 1989. "Les feux de forêt-mécanismes, comportements et environnement." Francesélection.

Triat-Laval, H., 1978. "Contribution pollenanalytique à l'histoire Tardiglaciaire et postglaciaire de la végétation de la basse vallée du Rhone." Thesis, Université d'Aix-Marseille III, France.

Tsutsuki, K., Kondo, R., Shiraishi, H., Kuwatsuka, S., Ohnohara Wetland Research group, 1993. Composition of lignin-degradation products, lipids, and opal phytoliths in a peat profile accumulated since 32000 years B.P. in central Japan. Soil Science Plant Nutrition 39 (3), 463-474.

Twiss, P.C., 1992. Predicted world distribution of C3 and C4 grass phytoliths, in: Rapp, G., Mulholland, S.C. (Eds.), Phytolith Systematics. Emerging Issues, Plenum Press, New York, pp. 113-128.

Twiss, P.C., Suess, E., Smith, R.M., 1969. Morphological classification of grass phytoliths. Soil Science Society of America Proceedings 33, 109-115.

Verdin, P, Berger, J.F., Lopez-Saez, J.A., 2001. Contribution of phytolith analysis to the understanding of historical agrosystems in the Rhône mid-valley (Southern France), in: Meunier, J.D., Colin, F. (Eds.), Phytoliths: Applications in Earth Sciences and Human History, A.A. Balkema Publishers, pp. 155-172.

Vernet, J.L., Thiébault, S., 1987. An approach to northwestern Mediterranean recent prehistoric vegetation and ecologic implications. Journal of Biogeography 14, 117-127.

Vernet, J.L., Thiébault, S., Heinz, C., 1987. Nouvelles données sur la végétation préhistorique postglacaire méditerranéenne d'aprés l'analyse anthracologique. Actes du colloque international "Premières communautés paysannes en Méditerranée occidentale," Montpellier 1983, CNRS, 87-94. 